УДК 577.19:577.152.321

\title{
ВЛИЯНИЕ ОБРАБОТКИ СЕМЯН ТРИТЕРПЕНОВЫМИ ГЛИКОЗИДАМИ НА АКТИВНОСТЬ ПЕРОКСИДАЗЫ, ИУК-ОКСИДАЗЫ И ПОЛИФЕНОЛОКСИДАЗЫ В ПРОРОСТКАХ ПШЕНИЦЫ
}

\author{
(C) Э.С. Давидяни
}

Ставропольский научно-исследовательский институт сельского хозяйства
Россельхозакадемии, ул. Никонова, 49, Михайловск, Ставропольский край,
356241 (Россия), e-mail: ei_davidyants@mail.ru

Изучено влияние обработки семян пшеницы Triticum aestivum L. водными растворами (5; 10 мкM) гликозидов олеаноловой кислоты, выделенных из Silphium perfoliatum L. (сильфиозиды B, C, Е, G и их прогенины) на активность пероксидазы, ИУК-оксидазы и полифенолоксидазы в проростках. Выявлено изменение активности ферментов в обработанных гликозидами прорастающих зерновках, корнях и надземной части проростков. Полученные результаты свидетельствуют о возможном влиянии экзогенных тритерпеновых гликозидов на уровень эндогенного ауксина в проростках пшеницы.

Ключевые слова: Silphium perfoliatum L., Triticum aestivum L., тритерпеновые гликозиды, пероксидаза, ИУКоксидаза, полифенолоксидаза.

\section{Введение}

В регулировании физиологических и биохимических процессов, лежащих в основе роста и развития растений, наряду с фитогормонами, по-видимому, могут участвовать и другие эндогенные биорегуляторы, роль которых изучена еще недостаточно. К числу таких биорегуляторов можно отнести тритерпеновые гликозиды (ТГ), которые представляют широко распространенную и структурно разнообразную группу вторичных метаболитов растений.

Особенность рострегулирующей активности ТГ заключается в проявлении ими эффектов, характерных для разных групп фитогормонов, в том числе и для ауксинов (стимуляция роста корней, индукция корнеообразования у черенков) [1]. Высокая активность ТГ в ряде биотестов явилась предпосылкой для разработки способов возможного практического использования этих соединений в растениеводстве в качестве регуляторов роста [2, 3].

Для понимания механизма рострегулирующего действия ТГ немаловажное значение имеет выяснение их влияния на активность ферментов, участвующих в метаболизме фитогормонов, в частности индолил-3-уксусной кислоты (ИУК).

Важнейшая роль в процессе окисления ИУК принадлежит пероксидазе (ПО, КФ. 1.11.1.7), оксидоредуктазе с высокой ферментативной активностью и широкой субстратной специфичностью [4]. ИУК можно рассматривать как специфический субстрат пероксидаз растений, поскольку в молекуле фермента обнаружены специфические центры связывания гормона [5]. Определенные изоферменты ПО, функционирующие как ИУК-оксидазы (ИУКО), окисляют ИУК до соединений, не содержащих индольной группы, и тем самым регулируют уровень гормона в тканях. Выявлено также участие ПО в метаболизме другого фитогормона - этилена [6].

Выполняя важные функции в общем метаболизме клетки, ПО катализируют окисление субстратов

Давидяни Элеонора Сергеевна - старший научный сотрудник, кандидат химических наук, доцент, e-mail: ei_davidyants@mail.ru (фенолов, индофенолов, ароматических аминов, аминокислот, аскорбиновой кислоты, НАДН, НАДФН и др.) за счет кислорода перекисей, преимущественно 
пероксида водорода (пероксидазное окисление) или молекулярного кислорода (оксидазное, оксигенозное окисление [7].

Функционально близким ПО ферментом является о-дифенолоксидаза (о-дифенол: кислородоксидоредуктаза, КФ 1.10.3.1, катехолоксидаза, полифенолоксидаза, ПФО), катализирующая окисление орто-дифенолов, в присутствии молекулярного кислорода. Донорами водорода могут быть различные клеточные метаболиты: аскорбиновая кислота, аминокислоты, органические кислоты, каротиноиды, восстановленный цитохром С, НАДН, НАДФН, некоторые алкалоиды [8].

Кроме того, установлено, что ПФО и ИУКО имеют общий активный центр на апоферменте [9], и высказано предположение, что они оказывают сходное действие и регулируют содержание ИУК [10].

Таким образом, ПО, ИУКО и ПФО способны изменять активность ИУК в тканях, влиять на баланс фитогормонов, следовательно, участвовать в регуляции ростовых процессов. Действие ПО и ПФО на рост может осуществляться также опосредованно через их участие в процессах дыхания и фотосинтеза.

Целью настоящей работы явилось изучение влияния обработки семян тритерпеновыми гликозидами на пероксидазную, ИУК-оксидазную и полифенолоксидазную активность в проростках озимой пшеницы.

\section{Экспериментальная часть}

В качестве объектов исследований использовали 3-0- $\beta$-D-глюкопиранозид олеаноловой кислоты (I), 3-0- $\beta$-D-глюкопиранозил $(1 \rightarrow 2)-0-\beta$-D-глюкопиранозид олеаноловой кислоты (3-0- $\beta$-D-софорозид олеаноловой кислоты, II); 3,28-ди-0- $\beta$-D-глюкопиранозид олеаноловой кислоты (сильфиозид B, III); 3-0-[ $\beta$-Dглюкопиранозил $(1 \rightarrow 2)-(6-0$-ацетил)- $\beta$-D-глюкопиранозид]; 28-0- $\beta$-D-глюкопиранозид олеаноловой кисло-

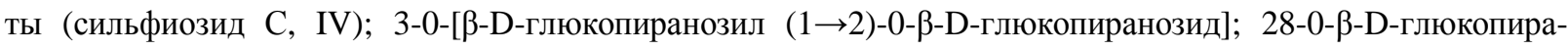
нозид олеаноловой кислоты (сильфиозид E, V); 3-0- $\beta$-D-глюкопиранозид - 28-0- $\beta$-D-глюкопиранозид олеаноловой кислоты (сильфиозид G, VI).

Сильфиозиды (III-VI) получали из надземной части сильфиума (сильфии) пронзеннолистного Silphium perfoliatum L. (Asteraceae), собранной в фазу цветения в Ставропольском ботаническом саду.

Выделение и подтверждение идентичности веществ проводили как описано в работах $[11,12]$. Гликозиды I и II получали омылением соответственно сильфиозидов В (III) и Е (V) [11, 13].

Опыты проводили на семенах озимой мягкой пшеницы Triticum aestivum L. сорта Авеста. Обработку семян исследуемыми веществами осуществляли по общепринятой методике, «полусухим» способом. Для этого семена интенсивно встряхивали с водными растворами гликозидов из расчета 1 мл/100 г семян. В контроле семена обрабатывали дистиллированной водой.

Обработанные семена сушили при комнатной температуре. Затем проращивали в течение 7 сут в чашках Петри на фильтровальной бумаге, смоченной 6 мл дистиллированной воды в термостате при температуре $22-24{ }^{\circ} \mathrm{C}$. Семисуточные проростки использовали для определения активности ферментов.

Активность ПО определяли по методу Бояркина [14]. Экстракт фермента получали после гомогенизации растительного материала в ацетатном буфере с рН 5.4. О скорости окисления бензидина пероксидазой в присутствии пероксида водорода судили по степени увеличения оптической плотности при 590 нм, рассчитывая активность в единицах, отнесенных к 1 г сырой ткани в минуту.

Активность ИУКО определяли по методу Гамбурга [15]. Для получения ферментного экстракта навеску свежей растительной ткани растирали в охлажденной ступке с добавлением охлажденного 0,02 М фосфатного буфера $\mathrm{pH}$ 6,1. После 30-минутного настаивания в холодильнике гомогенат (общий объем 10 мл) центрифугировали при $8000 \mathrm{~g}$ в течение 10 мин и супернатант использовали как экстракт фермента. Реакционная смесь (общий объем 10 мл) содержала: 1 мл $10^{-3} \mathrm{M}$ 2,4-дихлорфенола, 1 мл $10^{-3} \mathrm{M} \mathrm{MnCl}_{2}$, 2 мл $10^{-3}$ М ИУК (Serva, Германия), 4 мл 0,02 М фосфатного буфера рН 6,1 и 2 мл экстракта фермента. Смесь встряхивали на шейкере (Elpan, Польша) в течение 1 ч. Активность ИУКО определяли по убыли ИУК в реакционной среде, которая давала с реактивом Сальковского малиновое окрашивание. Оптическую плотность растворов измеряли при 490 нм. Для определения концентрации ИУК в среде использовали стандартный раствор ИУК известной концентрации (10 мг/л). Активность фермента рассчитывали в микрограммах разрушенной ИУК на единицу сырой массы в минуту.

Активность ПФО определяли спектрофотометрически по изменению оптической плотности реакционной смеси при 420 нм, содержащей 0,5 мл фосфатного буфера с рH 7,4, 0,5 мл 0,05 М пирокатехина и 0,5 мл экстракта фермента, полученного гомогенизацией растительного материала в 1/15 М фосфатном 
буфере с рН 7,4 в присутствии полиамида [14]; активность рассчитывали в относительных единицах на 1 г сырой ткани за 1 мин.

Измерение оптической плотности растворов в экспериментах проводили на спектрофотометре Spekol (Carl Zeiss, Германия).

В таблице и на графиках представлены средние значения опытов, каждый из которых состоял из 2-3 независимых экспериментов при трех аналитических повторностях, и их стандартные ошибки.

\section{Обсуждение результатов}

Взятые для исследования гликозиды олеаноловой кислоты различались строением углеводной части. Моносахаридный состав гликозидов представлен преимущественно остатками D-глюкозы, за исключением гликозида G (VI), содержащего также остаток D-глюкуроновой формулы кислоты.

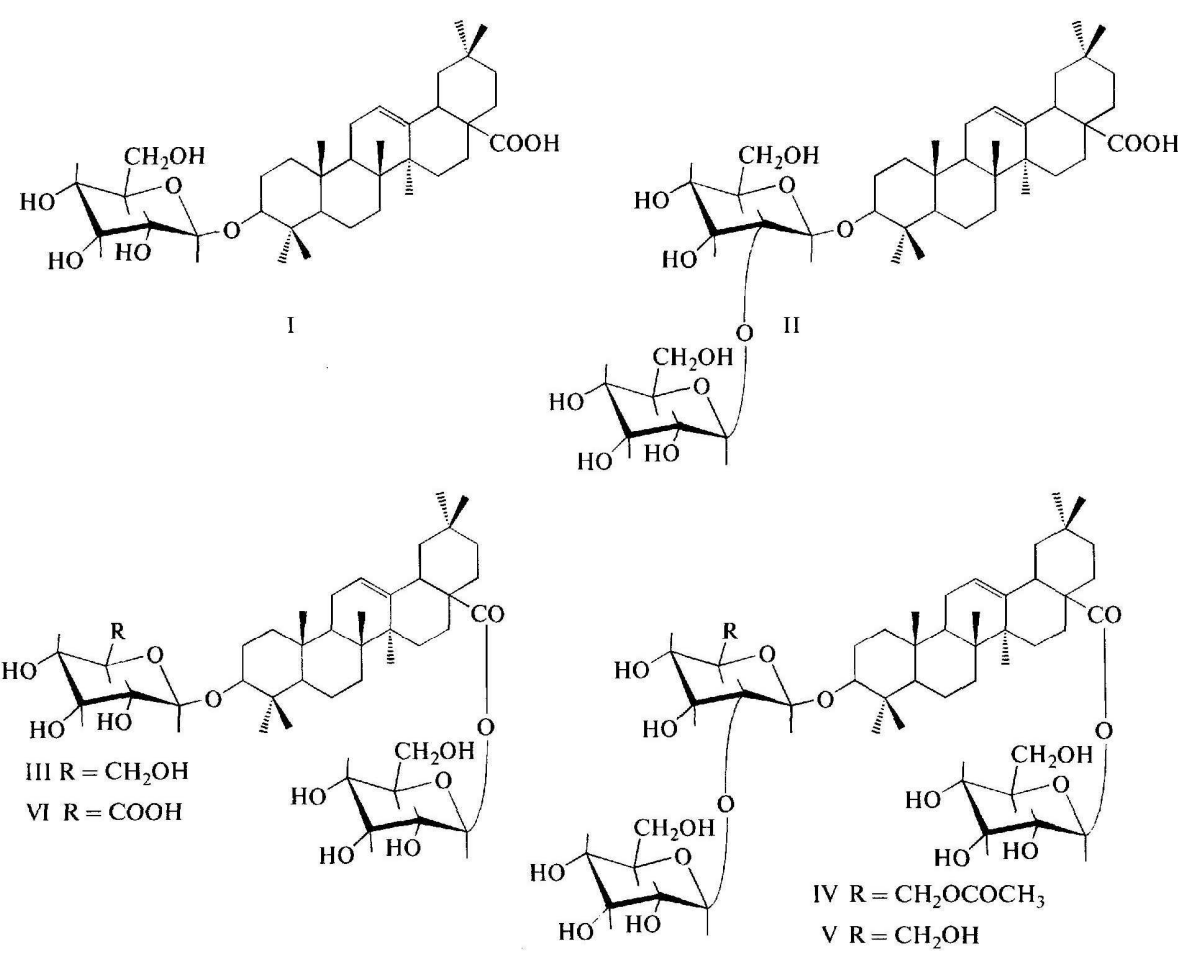

Обработка семян озимой пшеницы оптимальными ростстимулирующими концентрациями исследуемых веществ вызывала увеличение активности ПО в прорастающих зерновках в 1,4-1,8 раза относительно контроля (табл.). Существенных отличий в активности гликозидов не установлено, но отмечается несколько больший эффект триозидов (сильфиозидов С и Е) по сравнению с биозидами (II, III, VI). Действие концентрации сильфиозида Е 0,5 мкМ было практически таким же эффективным, как и действие концентрации 5,0 мкМ, в то время как понижение концентрации сильфиозида С до 0,5 мкМ приводило к заметному снижению его активности.

Если под влиянием ТГ наблюдалось повышение активности ПО в зерновках по сравнению с контролем, то в корнях и надземной части проростков, напротив, понижение (рис., а). После обработки семян пшеницы растворами моно-, би- и триозидов олеаноловой кислоты (I, II, V) активность ПО в корнях понижалась соответственно на 22,15 и $16 \%$, в надземной части проростков - соответственно на 30,35 и $23 \%$ по сравнению с контролем. Аналогичное действие оказала обработка семян растворами этих соединений на активность ИУКО в корнях и в надземной части проростков, активность фермента в корнях была соответственно на 33, 29 и 24\%, а в надземной части - на 33, 44 и 39\% ниже, чем в контроле, причем наблюдалось более заметное понижение ауксиноксидазной активности по сравнению с пероксидазной. В зерновках повышение активности ПО, вызванное действием исследуемых концентраций ТГ, не сопровождалось повышением активности ИУКО, а отмечалась тенденция к ее понижению (табл., рис., б). 
Влияние экзогенных тритерпеновых гликозидов на активность пероксидазы, ИУК-оксидазы и полифенолоксидазы в прорастающих зерновках пшеницы

\begin{tabular}{|c|c|c|c|c|}
\hline Вещество & $\begin{array}{c}\text { Концентрация, } \\
\text { мкМ }\end{array}$ & $\begin{array}{l}\text { Пероксидаза, ед./Г } \\
\text { сырой массы мин }\end{array}$ & $\begin{array}{c}\text { ИУК-оксидаза, мкг/Г } \\
\text { сырой массы мин }\end{array}$ & $\begin{array}{l}\text { Полифенол-оксидаза, } \\
\text { ед./г сырой массы мин }\end{array}$ \\
\hline $\begin{array}{l}\text { Дистиллированная вода } \\
\text { (контроль) }\end{array}$ & - & $6977 \pm 195$ & $2,9 \pm 0,1$ & $11,5 \pm 0,3$ \\
\hline 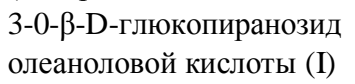 & 10,0 & $9840 \pm 263$ & $2,6 \pm 0,2$ & $13,3 \pm 0,5$ \\
\hline $\begin{array}{l}\text { 3-0- } \beta-\mathrm{D}-\text {-сфорозид олеа- } \\
\text { ноловой кислоты (II) }\end{array}$ & 5,0 & $10404 \pm 318$ & $2,4 \pm 0,1$ & $13,5 \pm 0,2$ \\
\hline Сильфиозид В (III) & 5,0 & $10186 \pm 145$ & $2,7 \pm 0,2$ & $13,8 \pm 0,3$ \\
\hline Сильфиозид C (IV) & 10,0 & $11233 \pm 287$ & $2,6 \pm 0,3$ & $13,2 \pm 0,5$ \\
\hline \multirow{3}{*}{ Сильфиозид Е (V) } & 0,5 & $8093 \pm 215$ & $3,0 \pm 0,2$ & $11,0 \pm 0,4$ \\
\hline & 5,0 & $12628 \pm 185$ & $2,6 \pm 0,2$ & $14,1 \pm 0,1$ \\
\hline & 0,5 & $12279 \pm 252$ & $2,7 \pm 0,3$ & $12,8 \pm 0,2$ \\
\hline Сильфиозид G (VI) & 5,0 & $10294 \pm 173$ & $2,8 \pm 0,1$ & $13,7 \pm 0,5$ \\
\hline
\end{tabular}
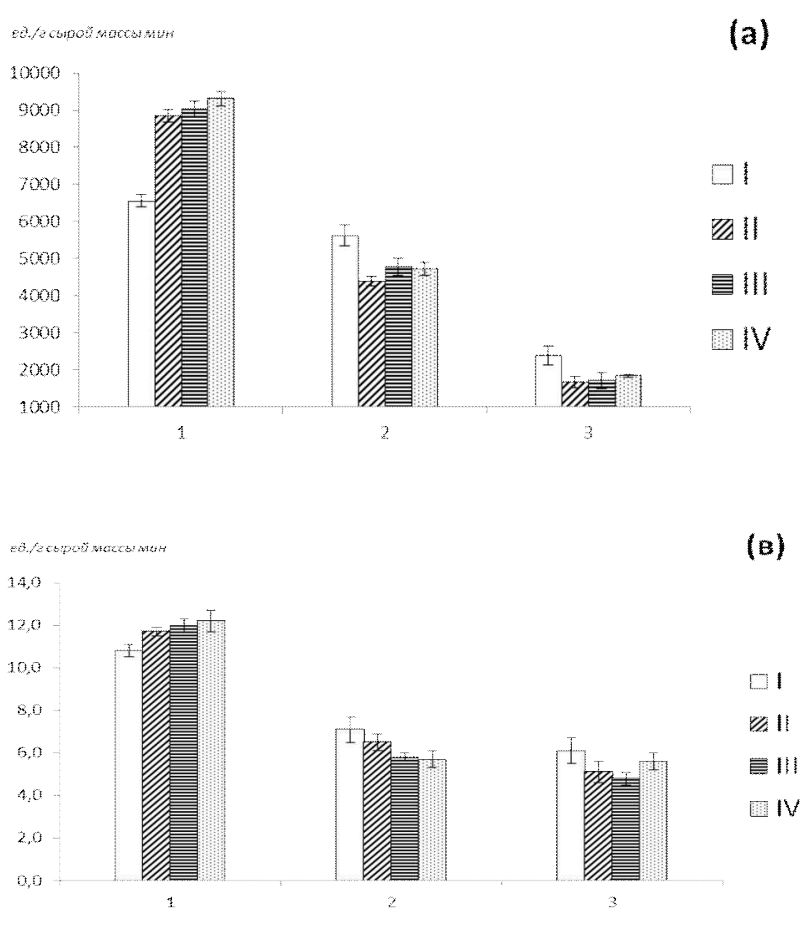

(a)

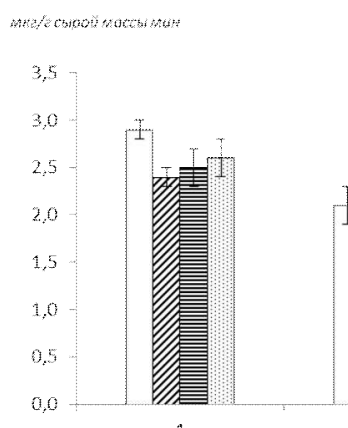

Влияние обработки семян озимой пшеницы (сорт

Авеста) оптимальными ростстимулирующими концентрациями ТГ на активность пероксидазы (а), ИУК-оксидазы (б) и полифенолоксидазы (в) в зерновках (1), корнях (2), надземной части (3) проростков: I - дистиллированная вода (контроль), II - 3-O- $\beta$-D-глюкопиранозид олеаноловой кислоты (10 мкM), III - 3-O- $\beta$-Dсофорозид олеаноловой кислоты (5 мкM), IV сильфиозид Е (5 мкМ)

Изменение уровня активности ПФО в различных частях проростков после обработки семян пшеницы растворами ТГ носило такой же характер, как и у ПО, но было менее выражено. В зерновках активность фермента превышала контроль на 15-23\%, в корнях и в надземной части была ниже, чем в контроле, соответственно на 8-20\% и на $18-21 \%$ (табл., рис., в).

Известно, что активность ПО и ПФО в зерне пшеницы существенно возрастает при прорастании [16]. Так, активность ПО в прорастающих зерновках на 7-й день проращивания повышалась в 4,5 раза по сравнению с покоящимися и коррелировала с показателями всхожести [17], в связи с чем авторами было выдвинуто предположение о возможном участии фермента в инициировании дыхательной активности митохондрий в начальный период прорастания зерен, когда их энергетические возможности резко понижены.

Если повышение активности ПО и ПФО при прорастании семян можно связать с активизацией дыхания и метаболизма фенолов, то в корнях и в надземной части проростков функциональная активность этих ферментов, по-видимому, в значительной мере обусловлена их участием в катаболизме ИУК. Наличие обратной корреляции между активностью ПО, ИУКО, количественным содержанием ИУК и ростом [7] дает основание полагать, что понижение под действием ТГ пероксидазной, ауксиноксидазной и полифенолоксидазной активности в проростках сопровождается повышением содержания эндогенной ИУК и интенсификацией ростовых процессов. 
В регуляции активности ферментов в прорастающих семенах ведущая роль отводится гиббереллинам $[18,19]$. Обработка семян гиббереллином $\mathrm{A}_{3}\left(\Gamma \mathrm{A}_{3}\right)$ повышала активность ПО в алейроновом слое семян ячменя и ПФО - в эндосперме пшеницы, причем с помощью ингибиторов биосинтеза белка и РНК было показано, что происходило активирование уже существующих ферментов [20].

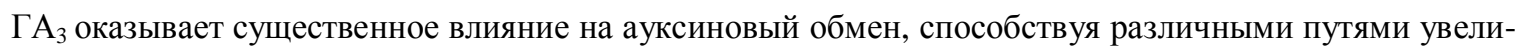
чению ИУК в тканях. После обработки ГА 3 наблюдалось повышение содержания ИУК в растениях и понижение активности ИУКО [21].

Анализ полученных данных позволяет выявить сходство в действии экзогенных ТГ и ГА 3 на активность исследуемых ферментов. Гиббереллиноподобное действие ТГ оказывали также на прорастание семян и рост гипокотиля салата, активность $\alpha$-амилазы в проростках пшеницы $[1,22]$. Однако при этом наблюдалась зависимость биологической активности гликозидов от их структуры, а именно от количества углеводных фрагментов, увеличение которых до трех в молекуле бис-триглюкозида (сильфиозида Е) приводило к потере стимулирующего эффекта. Что касается действия экзогенных ТГ на активность ПО, ИУКО, ПФО в проростках пшеницы, то такой закономерности не обнаружено. Это, по-видимому, обусловлено различным механизмом действия ТГ в случае $\alpha$-амилазы, когда происходила стимуляция новообразования фермента, и в случае ПО, ИУКО и ПФО, когда наблюдалась активация ферментов путем перевода латентной формы в активную.

Механизм ауксиноподобного действия ТГ, возможно. включает и другие пути воздействия на активность ИУК.

\section{Bыводbl}

1. Обработка семян пшеницы оптимальными рострегулирующими (5; 10 мкМ) концентрациями тритерпеновых гликозидов повышала в прорастающих зерновках активность пероксидазы (в 1,4-1,8 раза) и полифенолоксидазы (в 1,2 раза), что свидетельствует об активизации метаболических и, следовательно, ростовых процессов, при этом активность ИУК-оксидазы не увеличилась.

2. Тритерпеновые гликозиды, введенные в растения пшеницы путем обработки семян, способны понижать в корнях и надземной части проростков уровень активности пероксидазы, ИУК-оксидазы и полифенолоксидазы и тем самым способны регулировать активность эндогенной ИУК.

3. Существенных отличий в действии эндогенных моно- би- и триозидов олеаноловой кислоты на активность исследуемых ферментов не установлено.

4. На основе анализа данных литературы и полученных в результате исследования выявлено сходство в действии экзогенных тритерпеновых гликозидов и гиббереллина $\mathrm{A}_{3}$ на активность пероксидазы, ИУКоксидазы и полифенолоксидазы в проростках пшеницы.

\section{Список литературь}

1. Давидянц Э.С. Рострегулирующая активность тритерпеновых гликозидов Silphium perfoliatum (Asteraceae) // Растительные ресурсы. 2006. Т. 42, вып. 1. С. 127-136.

2. Патент 2200409 (РФ). Способ регулирования роста растений пшеницы / Э.С. Давидянц, И.В. Нешин // Б.И. 2000. №8.

3. Патент 2273996 (РФ). Способ стимулирования и роста черенков / Э.С. Давидянц, А.Ф. Кольцов // Б.И. 2006, №11.

4. Карташова Е.Р., Руденская Г.Н., Юрина Е.В. Полифункциональность растительных пероксидаз и их практическое использование // Сельскохозяйственная биология. 2000. №1. С. 62-70.

5. Газарьян И.Г., Хушпульян Д.М., Тишков В.И. Особенности структуры и механизма действия пероксидаз растений // Успехи биологической химии. 2006. Т. 46. С. 303-322.

6. Савич И.М. Пероксидазы - стрессовые белки растений // Успехи современной биологии. 1989. Т. 107, вып. 3. C. 406-417.

7. Садвакасова Г.Г., Кунаева Р.М. Некоторые физико-химические и физиологические свойства пероксидазы растений // Физиология и биохимия культурных растений. 1987. Т. 19, №2. С. 107-117.

8. Mayer A.M. Polyphenoloxidases in plant and fungi : Going places? // Phytochemistry. 2006. Vol. 67, N21. Pp. 23182331.

9. Srivastava O.P., van Huystee R.B. An Interrelationship among Peroxidase, JAA Oxigase and Polyphenol Oxigase from Peanut Cells // Can. J. Bot. 1977. Vol. 55. Pp. 2630-2635.

10. Mohamed-Vassen V., Splittstoesser W.E. The Relationship of Several Enzymes woit JAA and Phenol on Flower gnauction in Endive // Plant Growth Regul. 1990. Vol. 18. Pp. 133-139. 
11. Давидянц Э.С., Путиева Ж.М., Бандюкова В.А., Абубакиров Н.К. Тритерпеновые глюкозиды Silphium perfoliatum // Химия природных соединений. 1984. №1. С. 120-121.

12. Давидянц Э.С. Химическое строение тритерпеновых гликозидов Silphium perfoliatum: автореф. дисс. ... канд. хим. наук. Ташкент, 1985. $21 \mathrm{c.}$

13. Давидянц Э.С., Путиева Ж.М., Бандюкова В.А., Абубакиров Н.К. Тритерпеновые глюкозиды Silphium perfoliatum. III. Строение сильфиозида Е // Химия природных соединений. 1985. №6. С. 750-753.

14. Ермаков А.И., Арасимович В.В., Ярош Н.П., Перуанский Ю.В., Луковникова Г.А., Иконникова М.И. Методы биохимического исследования растений: под ред А.И. Ермакова, 3-е изд. перераб. и доп. Л., 1987. 430 с.

15. Гамбург К.З. Определение активности оксидазы индолилуксусной кислоты и ее ингибитора // Методы определения регуляторов роста и гербицидов. Л., 1966. С. 57-66.

16. Singh R., Singh D. Isoenzyme pattern of peroxidasa, polyphenoloxidasa and catalase during germination and early plant development of wheat (Triticum aestivum L.) // Biochem, Physiol. Pflanz. 1974. Vol. 167, N3. Pp. $233-237$.

17. Рогожин В.В., Курилюк Т.Т. Роль пероксидазы в механизмах покоя и прорастания зерновок некоторых злаковых культур // Известия Тимирязевской сельскохозяйственной академии. 2010. Вып. 4. С. 22-31.

18. Jacobson J.V., Higgins T.J. The influence of phytohormones on replication and transcription // Phytohormones and related compounds : A comprehensive treatise. 1978. Vol. 1. Pp. 515-582.

19. Муромцев Г.С., Чкаников Д.И., Кулаева О.А., Гамбург К.З. Основы химической регуляции роста и продуктивности растений. М., 1987. 383 с.

20. Физиология и биохимия покоя и прорастания семян: пер. с англ., под ред. М.Г. Николаевой и Н.В. Обручевой. М., 1982. 495 c.

21. Полевой В.В. Фитогормоны. Л., 1982. 248 с.

22. Давидянц Э.С. Влияние тритерпеновых гликозидов на активность $\alpha$ - и $\beta$-амилаз и содержание суммарного белка в проростках пшеницы // Прикладная биохимия и микробиология. 2011. Т. 47, №5. С. 530-536.

Поступило в редакиию 26 января 2013 г.

Davidyants E.S. EFFECT OF THE TREATMENT OF SEEDS OF TRITERPENOID GLYCOSIDES ON PEROXIDASE, JAA-OXIDASE. POLYPHENOLOXIDASE ACTIVITIES IN WHEAT SEEDLINGS

Stavropol Research Jnstitute of Agriculture, Russian Academy of Agricultaral Sciences, Nikonova 49, Mikhailovsk, Stavropol krai, 356241 (Russia), e-mail: ei_davidyants@mail.ru

The effect of the treatment of the Triticum aestivum L. seegs with 5; $10 \mu \mathrm{M}$ water solutions of oleanolic acid glycosides from Silphium perfoliatum L.(silphioside B, C, E, G and their progenins) on the activities peroxidase, JAA-oxidase and polyphenoloxidase in seedlings was studied. Changes in enzymes activities were revealed in glycosides - treated germinated seeds, roots and above-ground part seedlings. The results obtained showed an influenze of the exogenic tritepenoid glycosides on the endogenic level of auxin in wheat seedlings.

Keywords: Silphium perfoliatum L., Triticum aestivum L., triterpenoid glycosides, peroxidase, JAA-oxidase, polyphenoloxidase. 


\section{References}

1. Davidiants E.S. Rastitel'nye resursy, 2006, vol. 42, no. 1, pp. 127-136. (in Russ.).

2. Patent 2200409 (RU). 2000. (in Russ.).

3. Patent 2273996 (RU). 2006. (in Russ.).

4. Kartashova E.R., Rudenskaia G.N., Iurina E.V. Sel'skokhoziaistvennaia biologiia, 2000, no. 1, pp. 62-70. (in Russ.).

5. Gazar'ian I.G., Khushpul'ian D.M., Tishkov V.I. Uspekhi biologicheskoi khimii, 2006, vol. 46, pp. 303-322. (in Russ.).

6. Savich I.M. Uspekhi sovremennoi biologii, 1989, vol. 107, no. 3, pp. 406-417. (in Russ.).

7. Sadvakasova G.G., Kunaeva R.M. Fiziologiia i biokhimiia kul'turnykh rastenii, 1987, vol. 19, no. 2, pp. 107-117. (in Russ.).

8. Mayer A.M. Phytochemistry, 2006, vol. 67, no. 21, pp. 2318-2331.

9. Srivastava O.P., van Huystee R.B. Can. J. Bot., 1977, vol. 55, pp. 2630-2635.

10. Mohamed-Vassen V., Splittstoesser W.E. Plant Growth Regul., 1990, vol. 18, pp. 133-139.

11. Davidiants E.S., Putieva Zh.M., Bandiukova V.A., Abubakirov N.K. Khimiia prirodnykh soedinenii, 1984, no. 1, pp. 120-121. (in Russ.).

12. Davidiants E.S. Khimicheskoe stroenie triterpenovykh glikozidov Silphium perfoliatum: avtoref. diss. ... kand. khim. nauk. [Chemical structure of triterpene glycosides Silphium perfoliatum: author's Ph.D. in Chemistry dissertation.]. Tashkent,1985, 21 p. (in Russ.).

13. Davidiants E.S., Putieva Zh.M., Bandiukova V.A., Abubakirov N.K. Khimiia prirodnykh soedinenii, 1985, no. 6, pp. 750-753. (in Russ.).

14. Ermakov A.I., Arasimovich V.V., Iarosh N.P., Peruanskii Iu.V., Lukovnikova G.A., Ikonnikova M.I. Metody biokhimicheskogo issledovaniia rastenii. [Methods for biochemical study of plants]. Leningrad, 1987, 430 p. (in Russ.).

15. Gamburg K.Z. Metody opredeleniia reguliatorov rosta i gerbitsidov. [Methods for determination of growth regulators and herbicides]. Leningrad, 1966, pp. 57-66. (in Russ.).

16. Singh R., Singh D. Biochem, Physiol. Pflanz., 1974, vol. 167, no. 3, pp. $233-237$.

17. Rogozhin V.V., Kuriliuk T.T. Izvestiia Timiriazevskoi sel'skokhoziaistvennoi akademii, 2010, no. 4, pp. 22-31. (in Russ.).

18. Jacobson J.V., Higgins T.J. Phytohormones and related compounds : A comprehensive treatise, 1978, vol. 1, pp. $515-582$.

19. Muromtsev G.S., Chkanikov D.I., Kulaeva O.A., Gamburg K.Z. Osnovy khimicheskoi reguliatsii rosta i produktivnosti rastenii. [Fundamentals of chemical regulation of plant growth and productivity.]. Moscow, 1987, 383 p. (in Russ.).

20. Fiziologiia i biokhimiia pokoia i prorastaniia semian: Ed. M.G. Nikolaeva, N.V. Obrucheva. [Physiology and biochemistry of dormancy and germination of seeds]. Moscow, 1982, 495 p. (in Russ.).

21. Polevoi V.V. Fitogormony. [Phytohormones]. Leningrad, 1982, 248 p. (in Russ.).

22. Davidiants E.S. Prikladnaia biokhimiia i mikrobiologiia, 2011, vol. 47, no. 5, pp. 530-536. (in Russ.). 
